\title{
DEVELOPMENT, EVALUATION AND BIOLOGICAL ACTIVITIES OF HERBAL FORMULATION OF TALISA PATRA
}

\author{
YADAV DK ${ }^{1^{*}}$ \\ SGT College of Pharmacy, SGT University Gurugram (Haryana) India 122505 \\ *Corresponding Author: Dr. Dinesh Kumar Yadav: E Mail: dineshnbri08@gmail.com; Mobile \\ No: +917042348251 \\ Received $18^{\text {th }}$ April 2021; Revised $19^{\text {th }}$ May 2021; Accepted 25 ${ }^{\text {th }}$ June 2021; Available online $1^{\text {st }}$ March 2022 \\ https://doi.org/10.31032/IJBPAS/2022/11.3.5963
}

\section{ABSTRACT}

This study explores hepatoprotective and nephroprotective activities of herbal formulation of alcoholic extracts of Abies webbiana against experimental induced hepatotoxicity and nephrotoxicity by carbon tetra chloride and cisplatin respectively. Development of herbal suspension ware done simple procedure by using a suspending agent with water. The developed formulations were evaluated for organolepetic and physicochemical properties. Stability studies ware carried out formulation taking gallic acid as the marker compound for 90 days at two temperature; $30^{\circ} \mathrm{C}$ and $65 \% \mathrm{RH}$ and $40^{\circ} \mathrm{C}$ and $75 \% \mathrm{RH}$. Effects of suitable formulation were checked acute toxicity and on liver and kidney biomarkers. Formulation (FM-2) is better than FM-1 and FM-3 on the basis of their physicochemical parameters and their stability studies. Acute toxicity was performed and its biological activities of formulation (FM-2) at two doses 5 $\mathrm{ml} / \mathrm{kg}$ and $10 \mathrm{ml} / \mathrm{kg}$ (p. o.) were evaluated hepatotoxicity and nephrotoxicity studies. It was found that liver and kidney biomarkers reduced by formulation, which were increased by $\mathrm{CCl}_{4}$ and cisplatin respectively. Formulation is demonstrated the dose-dependent hepatic and nephro protective roles.

Keywords: Abies webbiana, Herbal formulation, Hepatoprotective, Nephroprotective 


\section{INTRODUCTION}

The World Health Organization has defined that herbal medicines are three types which are known as consists raw plant material, processed plant material and medicinal herbal products. Active ingredients of herbal finished labeled products are such as aerial or underground parts of plant, or other plant material. Globally herbal medicine has increased remarkably in line trend of people returning to natural therapies [1]. The systemic effect of administration of oral route of drug is the most important method [2]. Most of Ayurvedic formulations are liquid form and orally administered. There are a number of medicinal herbs in traditional system of medicine which are useful for the number of aliment [3]. Talispatra (Abies webbiana Lindl); commonly known as Talispatram in Sanskrit and Indian Silver Fir in English, is a large, tall, evergreen tree occurring in the Himalayan region from Kashmir to Assam in India. It comes under the Family: Pinaceae [4]. In Ayurveda leaves of the plant has been described various uses [5], the traditional system of Indian medicine and has been described for using against mukharoga, hikka, kasa, amadosha, and chhardi [6]. A. webbiana leaves have been reported as antibacterial, antifungal, antitumor, anti-inflammatory, anti-tussive, anti- spasmodic properties, mast cell stabilizing, anxiolytic, female infertility, febrifuge, central nervous system (CNS) depressant actions, effective against hyperglycemia, conception, rheumatism and high temperature [7]. The present study focused on development, evaluation of herbal formulation and to check their responses on liver and kidney induced by carbon tetra chloride and cisplatin respectively.

\section{MATERIALS AND METHODS}

\subsection{Collection and identification of plant material}

Plant materials (leaves) were collected from the forest of Tungnath and authenticated by Dr. A.K.S Rawat, Head, Department of Pharmacognosy and Ethno-Pharmacology, NBRI, Lucknow (Reference No: SMP0038). The voucher specimen was preserved for the future reference. The leaves were separated from the branches and dried at $40^{\circ} \mathrm{C}$ for one hour, and then pulverized by a mechanical grinder. The powder was passed through 40 mesh sieve and stored in a well closed vessel until use. The dried, powdered drug was used to prepare the extract.

\subsection{Material and method for Formulation development}

Powdered shade dried leaves of $A$. webbiana was extracted with $70 \% \mathrm{v} / \mathrm{v}$ of alcohol, by 
continuous heat extraction method by using a soxhlet extractor.

The extract was concentrated to a small volume and evaporated by rotator evaporator and finally on a water bath to dryness. The amount of plant extract required for the different formulations was calculated based on therapeutically effective dose. Effective doses of plant to be $400 \mathrm{mg} / \mathrm{kg}$ for the alcoholic extract from leaves of $A$. webbiana. Components of different herbal formulation are given in Error! Reference source not found..

\subsubsection{Procedure}

Three $(100 \mathrm{ml})$ beakers were used and in each beaker, $35 \mathrm{~g}$ of sorbitol solution $(70 \%)$ and $40 \mathrm{ml}$ of the distilled water were added and mixed thoroughly. Xanthum gum (in varying concentration) and sodium $\mathrm{CMC}$ were added in above mixtures and stirred properly. The extract was passed through 120 mesh sieve and added to the above mixture stirred for 30 minutes. Lastly methyl parabeen and flavor were added and the volume was made up to $100 \mathrm{ml}$ with distilled water.

\subsubsection{Evaluation of the formulation}

\subsubsection{Particle size distribution}

The particle size distribution was accomplished by using an optical microscope; a calibrated eyepiece was calibrated by using stage micrometer. The smallest division of the stage micrometer represents $0.01 \mathrm{~mm}$ in length eyepiece was kept with the stage micrometer and focused under high power. Both eyepiece were kept with the stage micrometer and focused under high power, and seen when they are superimposed. The stage micrometer was replaced with the slide of the formulation; the size was measured and all value noted. The size obtained was multiplied by a calibration factor to get the actual particle size dimension.

\subsubsection{Viscosity}

The viscosity of the prepared formulations ware measured by using Brookfield's Viscometer which attached to spindle no 21 . The prepared formulations were placed in separate $100 \mathrm{ml}$ beakers. The spindle of the Viscometer was introduced into the formulation and the reading was set to zero. The viscosity was measured at $250 \mathrm{rpm}$.

\subsubsection{3. pH measurement}

The $\mathrm{pH}$ of the prepared formulation was tested by using the calibrated $\mathrm{pH}$ meter. The prepared suspension formulation was taken different glass beakers. The electrode was dipped in the differing formulation and $\mathrm{pH}$ was noted.

\subsubsection{Sedimentation volume}

Sedimention volume was defined as the ratio 
of the equilibrium volume of sediment, $\mathrm{Vu}$, to the total volume of the suspension, Vo the largest fraction for the better is the suspendibility.

$$
\mathrm{F}=\mathrm{Vu} / \mathrm{Vo}_{\mathrm{O}}
$$

After storage and sedimentation, the cylinder was rotated through $360^{\circ}$ at $20 \mathrm{rpm}$. The end point was taken when the base of the cylinder is clear of sediment, including the uniformity of suspended particles. Each formulations F value was calculated.

\subsubsection{Ease of re-dispersibility}

The herbal formulations were allowed to settle completely in a measuring cylinder after settlement cylinder was inverted through 180 degrees and the number of inversions necessary to restore homogenous suspension was determined. One inversion was considered as $100 \%$ easy to disperse and every additional inversion reduced percentage ease of redispersibility by $5 \%{ }^{[8-9]}$.

\subsubsection{Stability studies}

Stability studies of the selected formulations were carried out by using Gallic acid as the marker compound for 90 days at two temperatures and $\mathrm{RH}$ i.e. $30{ }^{0} \mathrm{C}$ and $65 \% \mathrm{RH}$ and $40{ }^{\circ} \mathrm{C}$ and $75 \% \mathrm{RH}$. The samples were withdrawn and total amount of phenolics was measured at regular intervals for 15 days up to a total period of 90 days. Briefly, $1 \mathrm{ml}$ aliquots of developed herbal formulation or standard solution of Gallic acid was added to a $25 \mathrm{ml}$ volumetric flask containing $9 \mathrm{ml}$ of distilled water, $1 \mathrm{ml}$ Folins and Ciocalteus phenol reagents were added to the mixture and shaken. After 5 minutes, $10 \mathrm{ml}$ of $7 \%$ sodium carbonate solution was added and mixed with properly. This solution was immediately diluted up to $25 \mathrm{ml}$ with distilled $\mathrm{H}_{2} \mathrm{O}$ and mixed thoroughly. After incubation for 90 minutes at room temperature, the absorbance versus blank was determined at $750 \mathrm{~nm}$ using double beam UV-visible spectrophotometer (UV1800, Shimadzu, Japan). Total phenolic contents of developed herbal formulation were expressed in milligrams of Gallic acid equivalents (GAE) per gm of mixture of extracts. All the samples were analyzed in three replications [8-12]. The optimized formulation (FM-1 to FM-3) ware stored at $40^{\circ} \mathrm{C} \pm 20^{\circ} \mathrm{C} / 75 \% \mathrm{RH} \pm 5 \%$ RH. Samples from the stored formulation were taken and analyzed after every $15^{\text {th }}$ day for the period of 90 days for drug content uniformity calculations. At the end of the $90^{\text {th }}$ day samples were analyzed for viscosity, redispersibility and sedimentation volume. Formulations also analyzed by assay of phenolic compound at initial day and $90^{\text {th }}$ day of study [13]. 
2.3. Biological activities of formulation (FM-2)

\subsubsection{Animals}

Albino rats either sex of weight 150-200 g were used in the biological study. The animals were acclimatized for one week under laboratory conditions in the Sanskar College of Pharmacy and Research, Ghaziabad (U.P.). (Formerly known as SGIT, Ghaziabad, and U.P.). The animals were housed in polypropylene cages and maintained at $27^{\circ} \mathrm{C} \pm 2^{\circ} \mathrm{C}$ under 12 hrs dark / light cycle. They were fed with standard feed and water ad libitum was provided. The husk of cages was changed thrice a week for maintaining the hygeinity. Changing husk of the cages for maintaining the hygeinity and maximum comfort to animals has been done thrice in a weak up to entire the study. Ethical clearance for handling the animals was taken out from the Institutional animal's ethical committee prior to the beginning of the project work. Institutional animal's ethical committee (IAEC, Registration No SGIT/2014/04) has been given approval prior to the beginning of the work.

\subsubsection{Acute toxicity study}

On the basis of physical parameters, it concluded that formulation (FM-2) is the best out of all formulations. Different doses (1.25, 7.5 and $50 \mathrm{ml} / \mathrm{kg}$, p.o.) of FM-2 were administered to the animals were used for acute toxicity in accordance with Organization for Economic Cooperation Development (OECD, 2002) guideline 423 [14]. Three rats, simultaneously dosed at intervals of $48 \mathrm{hrs}$, were used for the test. Observation of cages side done once daily cage which included autonomic (salivation, lacrimation, perspiration, piloerection, urinary incontinence and defecation) changes in skin, fur, eyes, mucous membrane (nasal), and central nervous system (drowsiness, gait, tremors and convulsions) changes., If any Mortality was determined over a period of 2 weeks and animals were humanely sacrificed.

\subsubsection{Method for Evaluation of}

\section{Hepatoprotective Activity}

In the dose response experiment this was categorized in 4 groups and 6 animals either sex rats were taken randomly in each groups assigned.

Group-I Animals (-ve control) were administered $\quad(1 \mathrm{ml} / \mathrm{kg}) \quad$ distill water (p. o.) for 5 days.

Group-II Animals (+ ve control) were administered $(0.1 \mathrm{ml} / \mathrm{kg}) \mathrm{CCl}_{4}$ (i.p.) for 5 days.

Group-III Animals were orally administered formulation $\left(\mathrm{CCl}_{4}\right.$ $+05 \mathrm{ml} / \mathrm{kg}$ ) for 5 days. 
Group-IV Animals were orally taken before and after the experiment for administered formulation $\left(\mathrm{CCl}_{4} \quad\right.$ calculating \% changed in body weight. The $+10 \mathrm{ml} / \mathrm{kg}$ ) for 5 days.

Animals were humanely sacrificed on the $6^{\text {th }}$ day under mild ether anesthesia. Blood samples were collected for evaluating the serum biochemical parameters. Serum glutamate pyruvate transaminase (SGPT), Serum glutamate oxaloacetate transaminase (SGOT), Serum alkaline phosphates (SALP), serum total bilirubin and serum direct bilirubin were estimated by commercially available kits [15-19].

\subsubsection{Method for Evaluation of}

\section{Nephroprotective Activity}

In the dose response experiment, albino rats were taken randomly assigned into 4 groups of 6 individuals each.

Group-I Animals (-ve control) were administered $1 \mathrm{ml}$ distill water p.o., for 7 days.

Group-II Animals (+ve control) were administered Cisplatin (6 mg/kg, i.p.), for 7 days.

Group-III Animals were orally administered formulation (Cisplatin + $05 \mathrm{ml} / \mathrm{kg}$ ) for 7 days.

Group-IV Animals were orally administered formulation (Cisplatin + $10 \mathrm{ml} / \mathrm{kg}$ ) for 7 days.

The body weight of all the animals were 
5.9. The evaluation and quality of different formulation (FM-1 to FM-3) and parameters of quality via sedimentation rate, viscosity, $\mathrm{pH}$ and redispersibility were found satisfactory. The results revealed that formulations FM-3 is better for sedimentation rate, but has the disadvantage of high viscosity due to higher concentration of xanthum gum and low redispersibility. However, FM-2 is reasonably easily redispersible with favorable viscosity by having a slightly low sedimentation rate. Stability study of formulations at $30^{\circ} \mathrm{C}$ and $65 \% \mathrm{RH}$ and $40^{\circ} \mathrm{C}$ and $75 \% \mathrm{RH}$ were found stable as shown in (Table to

Table). On the basis of the above mentioned parameters it was found that FM-2 is best formulation so that the biological activities were performed. There was no toxicity effect of suspension FM-2 in rats and showed $\mathrm{CCl}_{4}$ and cisplatin induced hepatic and nephron protective activities at dose dependent manner. Error! Reference source not found. and Error! Reference source not found. Illustrated the effects of formulation leaves of A. webbiana on liver and kidney biomarkers parameters such as SGOT, SGPT, SALP and bilirubin for the liver and for kidney biomarkers like serum BUN, serum creatinine and serum protein; and \% changed in body weight were evaluated. From the above result, it may be concluded that the FM-2 formulation possesses significant hepatoprotective and nephroprotective activity. An accelerated stability studies have been performed for 90 days, according to $\mathrm{ICH}$ guideline at $30^{\circ} \mathrm{C}$ and $65 \% \mathrm{RH}$ and $40^{\circ} \mathrm{C}$ and $75 \% \mathrm{RH}$.

Table 1: Ingredient used in development of formulation

\begin{tabular}{|c|c|c|c|}
\hline Ingredients (\% w/w) & FM-1 & FM-2 & FM-3 \\
\hline Alcoholic extract & $10 \mathrm{~g}$ & $10 \mathrm{~g}$ & $10 \mathrm{~g}$ \\
\hline Xanthum gum & $0.20 \%$ & $0.25 \%$ & $0.35 \%$ \\
\hline Sodium CMC & $2 \mathrm{~g}$ & $2 \mathrm{~g}$ & $2 \mathrm{~g}$ \\
\hline Sorbitol $70 \%$ liquid & $35 \mathrm{~g}$ & $35 \mathrm{~g}$ & $35 \mathrm{~g}$ \\
\hline Methyl parabeen & $0.20 \%$ & $0.20 \%$ & $0.20 \%$ \\
\hline Lemon oil & $0.01 \%$ & $0.01 \%$ & $0.01 \%$ \\
\hline q. s. $\quad$ Purified water & $100 \mathrm{ml}$ & $100 \mathrm{ml}$ & $100 \mathrm{ml}$ \\
\hline
\end{tabular}

Table 2: Physical parameters of prepared herbal suspensions

\begin{tabular}{|c|c|c|c|c|}
\hline \multirow{2}{*}{ S. No. } & \multirow{2}{*}{ Parameters } & \multicolumn{3}{|c|}{ Results } \\
\hline & & FM-1 & FM-2 & FM-3 \\
\hline 1 & Sedimentation volume & 0.73 & 0.86 & 0.91 \\
\hline 2 & $\begin{array}{l}\text { Viscosity } \\
\end{array}$ & 227 & 312 & 389 \\
\hline 3 & $\mathrm{pH}$ & 5.5 & 5.6 & 5.9 \\
\hline 4 & Particle Size $(\mu \mathrm{m})$ & 2.67 & 2.83 & 2.89 \\
\hline 5 & Redispersibility & 85 & 90 & 85 \\
\hline 6 & Taste & Sweet & Sweet & Sweet \\
\hline 7 & Colour & Green & Green & Green \\
\hline 8 & Assay in \% & 91 & 93 & 90 \\
\hline
\end{tabular}


Table 3: Stability study parameter of formulation FM-1 at $30^{\circ} \mathrm{C}$ and $65 \% \mathrm{RH}$ and $40^{\circ} \mathrm{C}$ and $75 \% \mathrm{RH}$

\begin{tabular}{|c|c|c|c|c|c|c|c|c|}
\hline \multirow{3}{*}{ S. No. } & \multirow{3}{*}{ Parameters } & \multicolumn{7}{|c|}{$30^{\circ} \mathrm{C}$ and $65 \% \mathrm{RH}$} \\
\hline & & \multicolumn{7}{|c|}{ Number of Days } \\
\hline & & $\mathbf{0}$ & 15 & 30 & 45 & 60 & 75 & 90 \\
\hline 1 & Sedimentation volume & 0.73 & 0.68 & 0.64 & 0.61 & 0.60 & 0.58 & 0.54 \\
\hline 2 & Viscosity (cps) & 227 & 229 & 234 & 234 & 244 & 244 & 267 \\
\hline 3 & $\mathrm{pH}$ & 5.5 & 5.4 & 5.4 & 5.2 & 5.2 & 5.1 & 5.1 \\
\hline 4 & Redispersibility & 90 & 85 & 75 & 75 & 70 & 70 & 70 \\
\hline 5 & Taste & Sweet & Sweet & Sweet & Sweet & Sweet & Sweet & Sweet \\
\hline 6 & Colour & Green & Green & Green & Green & Green & Green & Green \\
\hline 7 & Assay & 91 & - & - & - & - & - & $81.8 \%$ \\
\hline \multicolumn{9}{|c|}{$40^{0} \mathrm{C} \& 75 \% \mathrm{RH}$} \\
\hline 1 & Sedimentation volume & 0.73 & 0.63 & 0.61 & 0.65 & 0.60 & 0.52 & 0.50 \\
\hline 2 & Viscosity & 227 & 231 & 243 & 243 & 248 & 258 & 256 \\
\hline 3 & $\mathrm{pH}$ & 5.5 & 5.4 & 5.4 & 5.3 & 5.3 & 5.0 & 5.0 \\
\hline 4 & Redispersibility & 90 & 85 & 75 & 75 & 70 & 65 & 65 \\
\hline 5 & Taste & Sweet & Sweet & Sweet & Sweet & Sweet & Sweet & Sweet \\
\hline 6 & Colour & Green & Green & Green & Green & Green & Green & Green \\
\hline 7 & Assay & 91 & - & - & - & - & - & $78.3 \%$ \\
\hline
\end{tabular}

Table 4: Stability study parameters of formulation FM-2 at $30^{\circ} \mathrm{C}$ and $65 \% \mathrm{RH}$ and $40^{\circ} \mathrm{C}$ and $75 \% \mathrm{RH}$

\begin{tabular}{|c|c|c|c|c|c|c|c|c|}
\hline \multirow{3}{*}{ S. No. } & \multirow{3}{*}{ Parameters } & \multicolumn{7}{|c|}{$30^{\circ} \mathrm{C}$ and $65 \% \mathrm{RH}$} \\
\hline & & \multicolumn{7}{|c|}{ Number of Days } \\
\hline & & 0 & 15 & 30 & 45 & 60 & 75 & 90 \\
\hline 1 & Sedimentation volume & 0.86 & 0.84 & 0.84 & $\mathbf{0 . 8 3}$ & 0.83 & 0.81 & 0.81 \\
\hline 2 & Viscosity (cps) & 312 & 313 & 327 & 334 & 334 & 334 & 337 \\
\hline 3 & $\mathrm{pH}$ & 5.6 & 5.6 & 5.6 & 5.4 & 5.4 & 5.3 & 5.3 \\
\hline 4 & Redispersibility & 90 & 90 & 85 & 85 & 85 & 85 & 85 \\
\hline 5 & Taste & Sweet & Sweet & Sweet & Sweet & Sweet & Sweet & Sweet \\
\hline 6 & Colour & Green & Green & Green & Green & Green & Green & Green \\
\hline 7 & Assay & $93 \%$ & - & - & - & - & - & $91.8 \%$ \\
\hline \multicolumn{9}{|c|}{$40^{\circ} \mathrm{C} \& 75 \% \mathrm{RH}$} \\
\hline 1 & Sedimentation volume & 0.86 & 0.73 & 0.71 & 0.73 & 0.68 & 0.62 & 0.62 \\
\hline 2 & Viscosity & 312 & 341 & 343 & 343 & 348 & 348 & 347 \\
\hline 3 & pH & 5.6 & 5.5 & 5.5 & 5.5 & 5.3 & 5.2 & 5.2 \\
\hline 4 & Redispersibility & 90 & 85 & 80 & 80 & 80 & 80 & 80 \\
\hline 5 & Taste & Sweet & Sweet & Sweet & Sweet & Sweet & Sweet & Sweet \\
\hline 6 & Colour & Green & Green & Green & Green & Green & Green & Green \\
\hline 7 & Assay & $93 \%$ & - & - & - & - & - & $87.8 \%$ \\
\hline
\end{tabular}

Table 5: Stability study parameter of formulation FM-3 at $30^{\circ} \mathrm{C}$ and $65 \% \mathrm{RH}$ and $40^{\circ} \mathrm{C}$ and $75 \% \mathrm{RH}$

\begin{tabular}{|c|c|c|c|c|c|c|c|c|}
\hline \multirow[b]{2}{*}{ S. No. } & \multirow[b]{2}{*}{ Parameters } & \multicolumn{7}{|c|}{$30^{\circ} \mathrm{C}$ and $65 \% \mathrm{RH}$} \\
\hline & & \multicolumn{7}{|c|}{ Number of Days } \\
\hline 1 & Sedimentation volume & 0.91 & 0.87 & 0.87 & 0.84 & 0.80 & 0.79 & 0.76 \\
\hline 2 & Viscosity (cps) & 389 & 393 & 400 & 413 & 416 & 424 & 425 \\
\hline 3 & pH & 5.9 & 5.6 & 5.6 & 5.7 & 5.7 & 5.7 & 5.7 \\
\hline 4 & Redispersibility & 90 & 80 & 75 & 75 & 70 & 70 & 70 \\
\hline 5 & Taste & Sweet & Sweet & Sweet & Sweet & Sweet & Sweet & Sweet \\
\hline 6 & Colour & Green & Green & Green & Green & Green & Green & Green \\
\hline \multicolumn{9}{|c|}{$40^{\circ} \mathrm{C} \& 75 \% \mathrm{RH}$} \\
\hline 1 & Sedimentation volume & 0.91 & 0.73 & 0.71 & 0.73 & 0.68 & 0.62 & 0.62 \\
\hline 2 & Viscosity & 389 & 391 & 398 & 433 & 341 & 448 & 457 \\
\hline 3 & pH & 5.9 & 5.5 & 5.5 & 5.5 & 5.3 & 5.2 & 5.2 \\
\hline 4 & Redispersibility & 90 & 80 & 75 & 75 & 70 & 70 & 65 \\
\hline 5 & Taste & Sweet & Sweet & Sweet & Sweet & Sweet & Sweet & Sweet \\
\hline 6 & Colour & Green & Green & Green & Green & Dark green & Dark green & Dark green \\
\hline
\end{tabular}


Table 6: Effect of formulation FM-2 on liver biomarkers

\begin{tabular}{|c|c|c|c|c|c|}
\hline \multirow{3}{*}{ Group } & \multicolumn{5}{|c|}{ Level of biochemical parameters liver } \\
\hline & \multirow[t]{2}{*}{ SGOT (IU/I) } & \multirow[t]{2}{*}{ SGPT (IU/I) } & \multirow[t]{2}{*}{ SALP (IU/I) } & \multicolumn{2}{|c|}{ Serum bilirubin (mg/l) } \\
\hline & & & & Total & Direct \\
\hline Group I & $36.4 \pm 1.92$ & $43.66 \pm 1.83$ & $111.66 \pm 4.32$ & $0.35 \pm .023$ & $0.156 \pm 0.20$ \\
\hline Group II & $84 \pm 2.60 \mathrm{a} * * *$ & $86.33 \pm 1.21^{\mathrm{a} * * *}$ & $212.5 \pm 2.88^{\mathrm{a} * * *}$ & $0.86 \pm 0.33^{\mathrm{a} * *}$ & $0.585 \pm 0.05^{a} * *$ \\
\hline Group III & $60.5 \pm 1.37 * *$ & $61.5 \pm 1.04 * *$ & $147.16 \pm 5.52 * *$ & $0.55 \pm 0.066 * *$ & $0.271 \pm 0.042 * *$ \\
\hline Group IV & $44.5 \pm 5.04 * * *$ & $53.16 \pm 1.16 * * *$ & $133.6 \pm 3.93 * * *$ & $0.45 \pm 0.066 * * *$ & $0.185 \pm 0.03 * * *$ \\
\hline
\end{tabular}

Group I - Normal control; Group II - $\mathrm{CCl}_{4}$ treated; Group III- Formulation (5 ml/ kg) + $\mathrm{CCl}_{4}$; Group IV- Formulation

$(10 \mathrm{ml} / \mathrm{kg})+\mathrm{CCl}_{4}$. One way ANNOVA followed by Tukey's multiple comparison column test. Where * represent significant at $\mathbf{P}<0.05, * *$ represent more significant at $\mathbf{P}<0.01$ and $* * *$ represent highly significant compared with cisplatin group and ${ }^{\mathrm{a}^{*}}$ represent significant compared to control group

Table 7: Effect of formulation FM-2 on kidney biomarkers

\begin{tabular}{|c|c|c|c|c|}
\hline \multirow[b]{2}{*}{ Group } & \multicolumn{4}{|c|}{ Level of biochemical parameters of kidney } \\
\hline & $\begin{array}{c}\text { \%Change in body } \\
\text { weight }\end{array}$ & $\begin{array}{c}\text { Serum creatinine } \\
(\mathrm{mg} / \mathrm{dl})\end{array}$ & Serum BUN(mg/dl) & $\operatorname{Serum} \operatorname{protein}(\mathrm{g} / \mathrm{dl})$ \\
\hline Group I & $1.275 \pm 0.06$ & $0.781 \pm 0.01$ & $16.92 \pm 0.04$ & $3.887 \pm 0.09$ \\
\hline Group II & $13.55 \pm 0.955^{\mathrm{a} * * *}$ & $2.079 \pm 0.011^{\mathrm{a} * * *}$ & $26.87 \pm 0.06^{\mathrm{a} * * *}$ & $9.491 \pm 0.25^{\mathrm{a} * * *}$ \\
\hline Group III & $2.55 \pm 1.27 * *$ & $1.82 \pm 0.072 * *$ & $22.19 \pm 0.78 * *$ & $6.37 \pm 0.15 * *$ \\
\hline Group IV & $2.27 \pm 1.37 * * *$ & $1.11 \pm 0.062 * * *$ & $19.48 \pm 2.04 * * *$ & $5.49 \pm 0.27 * * *$ \\
\hline
\end{tabular}

Group I - Normal control; Group II - Cisplatin treated; Group III- Formulation (5 ml/ kg) + Cisplatin; Group IVFormulation (10 ml/kg) +Cisplatin. One way ANNOVA followed by Tukey's multiple comparison column test. Where * represent significant at $\mathbf{P}<0.05$, ** represent more significant at $\mathbf{P}<0.01$ and *** represent highly significant compared with cisplatin group and ${ }^{\mathrm{a}^{*}}$ represent significant compared to control group

\section{CONCLUSIONS}

In conclusion, FM-2 formulation demonstrated significant hepatoprotective and nephroprotective activities. Sedimentation value, $\mathrm{pH}$ value, viscosity has been decreases significantly during time period of $90^{\text {th }}$ day where as redispersibility increased, according to time, but the other characters were not changed during the time period. Overall, our formulation was demonstrated stable, suitable physicochemical characteristics and also showed significant hepatic and nephronprotective activities.

\section{Acknowledgement:}

Authors are thankful to the Director, Sanskar college of Pharmacy research (Uttar Pradesh) for providing the facilities and grant for research. The authors are also grateful to Dr. A.K.S Rawat, Head, Department of Pharmacognosy and Ethno-Pharmacology, National Botanical Research Institute, Lucknow (Uttar Pradesh) for plant identification and authentication

\section{Compliance with Ethical Standards}

\section{Conflict of interest}

The authors declare that there is no conflict of interest.

\section{REFERENCES}

[1] Sagar B.P.S. , Zafar R. and Panwar R. Herbal drug standardization, The Indian Pharmacist, 2005,4(35) 19-22.

[2] Chaudhury R.R. Herbal medicine for human health. World Health Organization Geneva, CBS Publishers 
and distributors LTD New Delhi 1999, 5, pp 32-33.

[3] Zafar R., Panwar R. and Sagar B.P.S. Herbal drug standardization, The Indian Pharmacist, 2005, 4(36) 21-25.

[4] Chatterjee A., Kotoky J., Das K.K., Banerji J. and Chakraborty T. Abiesin, a biflavonoid of Abies webbiana, Phytochemistry, 1984, 23,704.

[5] Sarkar S.K., Poddar G. and Mahato S.B. Glucoside from Abies webbiana, Planta Medica, 1986, 4, 219.

[6] Rawat A.K.S., Mehrotra S. and Shome U. Comparative pharmacognostical studies on the leaves of Abies spectabilis and Taxus wallichiana, International journal of Pharmacognosy, 1996, 34,378.

[7] Yadav D.K., Ghosh A.K. and Kumar B. Hepatotoxicity and nephrotoxicity activity of ethanol extract of abies webbiana lindl.leaves. IJPBS, 7(3) 2016, 226-30.

[8] Zografi G, Schott H. and Swarbrick J. Disperse Systems; In: Remington's Pharmaceutical Sciences. $18^{\text {th }}$ ed. Mack. Publishing Co, Easton, 1990, pp 257.

[9] Indian Pharmacopoeia , Govt. of India, Ministry of health and Family Welfare, Controller of Publications; Delhi, 1986(2). A-99.
[10] ICH Q1A (R2), Stability Testing of New Drug Substances and Products, 6 February; 2003.

[11] Narayana D.B.A, Stability studies of Ayurvedic Formulations, Pharma Times, 2005, 37(6) 45-50.

[12] Public Draft, WHO-Guidelines for Herbal Drug standardization, 2004.

[13] Dahanukar S.A. and Thatte U.M. Ayurveda Revisited, Popular Prakashan. 1994, 1-28.

[14] OECD, Guideline for testing of chemicals, Acute oral toxicity, Environmental Health and Safety monograph series on testing and adjustment No 423, 2002, 1.

[15] Zeeyaudin K, Setty R.C.S, Majid M.S.A. and Ibrahim M. Evaluation of hepatoprotective activity of Boswellia serrata leaves extracts in albino rats, Indian Drugs, 2010, 47(2)14.

[16] Kumar S.V.S and Mishra S.H Hepatoprotective activity of rhizomes of Cyperus rotundus Linn against carbon tetrachloride-induced hepatoxicity. Indian J of Pharm Sci, 2005, $67(1) 84$

[17] Girish C, Koner B.C.S., Jayanthi K.R., Rao B and Pradhan R.S.C. Hepatoprotective activity of six polyherbal formulations in paracetamol induced 
liver toxicity in mice, Indian $\mathrm{J}$ Med Res, 2009, 129, 569.

[18] Sharstry R.A., Biradar S.M., Mahadevan K.M. and Habbu P.V. Isolation and characterization of secondary metabolite from Amorphophallus paeoniifolius for hepatoprotective activity, Research J Pharm Bio and Chem Sci. 2010, $1(4) 429$.

[19] Suja S.R., Latha P.G., Pushpangadan P. and Rajasekharan S. Evaluation of hepatoprotective effects of Helminthostachyes zeylanica (L.) hook against carbon tetrachloride induced liver damage in Wister rats, J. Ethnopharmacol, 2004, 92, 61.

[20] Sdzuka Y., Shoji T. and Takinoy. Effects of cisplatin on the activities of enzymes which protects against lipid peroxidation. Biochem Pharmacol, 1992, 43, 1872-75.

[21] Hostetler K.Y. and Hall L.B. Inhibition of kidney lysosomal phospholipases A \& $\mathrm{C}$ by aminoglycoside antibiotics: Possible mechanism of aminoglycoside toxicity, Proc Natl Acad Sci, USA. 1982, 79, 1663.

[22] Rang H.P., Dale M.M., Ritter J.M. and Moore P.K. 5th(Ed). Pharmacology. Churchill living stone 2003, pp 728.
[23] Barry M., Brenner F.C., Rector. The kidney, 6th (Ed). W.B. Saunders Company. Philadelphia 2001, 1, pp367.

[24] Sreedevi K.B. and Prasad K.G. Protective effect of rutin against cisplatin-induced nephrotoxicity in rats, Journal of Natural Remedies, 2010, 10(2)144.

[25] Corcostegui R., Labeaga L., Arteche J.K. and Orjales A. Protective effect of hidrosmin against cisplatin induced acute nephrotoxicity in rats, J Pharm Pharmacol, 1998, 4: 465.

[26] Devi P.S. and Shaymal D.C.S. Protective effect of quercetin in cisplatin-induced cell injury in the rat kidney. Indian J Pharmacol, 1999, 31,422 .

[27] Annie S., Malini S. and Chandrika K.S. Protective effect of Pongamia pinnata flowers against cisplatin and gentamicin induced nephrotoxicity in rats, Ind J Exp Biol, 2003, 41,58-62. 